\title{
UPAYA PENINGKATAN HASIL BELAJAR SISWA PADA PEMBELAJARAN ALQURAN-HADITS MELALUI PENERAPAN MODEL M2E (MAPPING, MATRIX AND ELABORATION)
}

\begin{abstract}
Oleh:

Ading

Email:

adinga443@gmail.com

MAS Argayasa, Ciamis

This research aims to know the competence of teacher in designing the implementation of M2E learning model on the Alquran-Hadits subject matter with theme "definition of hadits, sunah, khobar and atsar," the implementation process of M2E learning model on the Alquran-Hadits subject matter with theme "definition of hadits, sunah, khobar and atsar," and the effectiveness of M2E learning model implementation on the Alquran-Hadits subject matter with theme "definition of hadits, sunah, khobar and atsar," in the grade 10th IPA of Madrasah Aliyah. Research method used in this article is classroom action research. The result research is 1) the competence of teacher in planning the learning of Alquran-Hadits with theme "definition of hadits, sunah, khobar and atsar" by M2E learning model, from cycle to cycle showed a good increase with the results of 62,14\% for the first cycle and $80 \%$ for the second cycle, 2) the competence of teacher in implementing the learning of Alquran-Hadits with theme "definition of hadits, sunah, khobar and atsar" by M2E learning model, from cycle to cycle showed a good increase with the results of 61,5\% for the first cycle and $78 \%$ for the second cycle, 3) Student learning outcomes in the first cycle 71,05; and second cycle 80,53.
\end{abstract}

Keywords: Learning Outcomes, Alquran-Hadits, M2E Learning Model

\section{PENDAHULUAN}

\section{Konteks Penelitian}

Di dalam UU No. 20 Tahun 2003 tentang Sistem Pendidikan Nasional, dinyatakan bahwa pendidikan nasional berfungsi mengembangkan kemampuan dan membentuk watak serta peradaban bangsa yang bermartabat dalam rangka mencerdaskan kehidupan bangsa, bertujuan untuk berkembangnya potensi peserta didik agar menjadi manusia yang beriman dan bertakwa kepada Tuhan Yang Maha Esa, berakhlak mulia, sehat, berilmu, cakap, kreatif, mandiri, dan menjadi warga negara yang demokratis serta bertanggung jawab. Untuk mencapai tujuan tersebut, salah satu bidang studi yang harus dipelajari oleh peserta didik di madrasah adalah pendidikan agama Islam, yang dimaksudkan untuk membentuk peserta didik menjadi ${ }^{1}$ manusia yang beriman dan bertakwa kepada Tuhan Yang Maha Esa serta berakhlak mulia.

Pendidikan agama Islam di madrasah aliyah terdiri atas empat mata pelajaran, yaitu: Alquran-Hadits, Akidah-Akhlak, Fikih, dan Sejarah Kebudayaan Islam. Masing-masing mata pelajaran tersebut pada dasarnya saling terkait, isi mengisi dan melengkapi. Alquran-Hadits merupakan sumber utama ajaran Islam, dalam arti ia merupakan sumber akidah-akhlak, syari'ah/fikih (ibadah, muamalah), sehingga kajiannya berada di setiap unsur tersebut. Akidah (usuluddin) atau keimanan merupakan akar atau

\footnotetext{
1 Jalaluddin and Abdullah Idi, Filsafat Pendidikan: Manusia, Filsafat Dan Pendidikan (Depok: Raja Grafindo Persada, 2016), 53.
} 
pokok agama. Syariah/fikih (ibadah, muamalah) dan akhlak bertitik tolak dari akidah, yakni sebagai manifestasi dan konsekuensi dari akidah (keimanan dan keyakinan hidup). Syari'ah/fikih merupakan sistem norma (aturan) yang mengatur hubungan manusia dengan Allah, sesama manusia dan dengan makhluk lainnya. Akhlak merupakan aspek sikap hidup atau kepribadian hidup manusia, dalam arti bagaimana sistem norma yang mengatur hubungan manusia dengan Allah (ibadah dalam arti khas) dan hubungan manusia dengan manusia dan lainnya (muamalah) itu menjadi sikap hidup dan kepribadian hidup manusia dalam menjalankan sistem kehidupannya (politik, ekonomi, sosial, pendidikan, kekeluargaan, Kebudayaan/seni, iptek, olahraga/kesehatan, dan lain-lain) yang dilandasi oleh akidah yang kokoh. Sejarah Kebudayaan Islam merupakan perkembangan perjalanan hidup manusia muslim dari masa ke masa dalam usaha bersyariah (beribadah dan bermuamalah) dan berakhlak serta dalam mengembangkan sistem kehidupannya yang dilandasi oleh akidah. ${ }^{2}$

Mata pelajaran Alquran-Hadits di madrasah aliyah adalah salah satu mata pelajaran Pendidikan Agama Islam yang merupakan peningkatan dari Alquran-Hadits yang telah dipelajari oleh peserta didik di Madrasah Ibtidaiyah (MI) - Madrasah Tsanawiyah (MTs). Peningkatan tersebut dilakukan dengan cara mempelajari, memperdalam serta memperkaya kajian Alquran dan haditsterutama menyangkut dasar-dasar keilmuannya sebagai persiapan untuk melanjutkan ke pendidikan menengah, serta memahami dan menerapkan tema-tema tentang manusia dan tanggung jawabnya di muka bumi, demokrasi serta pengembangan ilmu pengetahuan dan teknologi dalam perspektif Alquran dan hadits sebagai persiapan untuk hidup bermasyarakat. Secara substansial, mata pelajaran Alquran-Hadits memiliki kontribusi dalam memberikan motivasi kepada peserta didik untuk mempelajari dan mempraktikkan ajaran dan nilainilai yang terkandung dalam Alquran-Hadits sebagai sumber utama ajaran Islam dan sekaligus menjadi pegangan dan pedoman hidup dalam kehidupan sehari-hari. ${ }^{3}$

Namun nengapa rata-rata hasil belajar Alquran-Hadits masih belum optimal? Realitas di

\footnotetext{
2 Aisha Agusta, M Priyatna, and Agus Saripudin, "Pengaruh Hafalan Alquran Terhadap Prestasi Belajar Pada Mata Pelajaran Alquran Hadist Kelas XI IPA," in Prosiding Al Hidayah Pendidikan Agama Islam, 2018, 131-37.

3 Moch. Subekhan and Dea Umyati, "Pengaruh Metode Pembelajaran Talking Stick Terhadap Keaktifan Belajar
}

lapangan menunjukkan bahwa hasil belajar siswa Kelas X IPA MAS Argayasa Kabupaten Ciamis terhadap materi pokok "Pengertian hadits, sunah, khobar dan atsar" belum sesuai target kurikulumnya.. Aspek pemahaman konsep yang dicapai siswa rata-rata tiap kelas hanya 62,4\% tuntas, dengan KKM 75. Aspek keaktifan siswa, khususnya berani menjawab pertanyaan guru, bertanya, dan menyampaikan ide rata - ratanya hanya $11 \%$ dari 19 jumlah siswa.

Keadaan di atas menjadi PR bagi guru yang dalam pembelajaran Alquran-Hadits. Bagaimana hal itu bisa terjadi, padahal logikanya model dan prinsip pembelajaran Alquran-Hadits sudah dilaksanakan. Apanya yang kurang? Salah satu hal yang mendasari masalah tersebut adalah guru kurang kreatif dalam mengemas pelajaran. Hal ini bukan berarti bahwa tidak ada usaha untuk mengubah dan meningkatkan sistem yang telah dilakukan selama ini. Intinya guru harus mampu menerapkan model yang cocok untuk setiap konsep mata pelajaran yang akan disampaikannya. Guru harus inovatif dalam menyajikan berbagai topik pembelajaran. Setiap waktu guru harus mampu mengaransemen kurikulum yang dipakainya, mendesain pembelajaran yang bermakna dan memotivasi anak didik dalam menggali pengetahuan. ${ }^{4}$ Untuk itu perlu strategi pembelajaranyang bisa merangsang keaktifan siswa dalam bertanya dan menjawab pertanyaan dari guru atau teman lain. Lebih dari itu, model tersebut diharapkan dapat meningkatkan hasil belajar siswa.

Model pembelajaran M2E (Mapping, Matrix and Elaboration) adalah solusi paling tepat untuk mewujudkan pembelajaran Alquran-Hadits khususnya pada materi pokok "pengertian hadits, sunah, khobar dan atsar." Model pembelajaran M2E tidak saja membuat siswa jadi aktif tetapi juga dapat merangsang anak untuk belajar giat memahami konsep-konsep materi yang dipelajari. Unsur kompetisi anak sangat dominan dalam pembelajaran dengan model M2E. Siswa harus bisa membuat soal dan menjawabnya sendiri, selain itu juga harus dapat menjawab soal yang dibuat oleh siswa lain. Interaksi peserta didik sangat dominan dalm memecahkan masalah, sehingga terjadi hubungan komunikatif dan demokratif. Hakikat belajar dengan Model

Siswa Pada Mata Pelajaran Al-Qur'an Dan Hadits," Geneologi PAI: Jurnal Pendidikan Agama Islam 6, no. 1 (2019): 51-68, doi:10.32678/geneologipai.v6i1.1943.

${ }^{4}$ E Mulyasa, Menjadi Guru Profesional (Menciptakan Pembelajaran Kreatif Dan Menyenangkan) (Bandung: Remaja Rosdakarya, 2016), 75 . 
pembelajaran M2E adalah siswa dilatih untuk bekerja sama dalam kelompok memahami materi pelajaran.

\section{Perumusan Masalah}

Berdasarkan latar belakang masalah, ditemui bahwa rendahnya hasil belajar siswa pada pembelajaran Alquran-Hadits khususnya materi pokok, "pengertian hadits, sunah, khobar dan atsar", disebabkan dari faktor guru yaitu kurang bervariasi dalam menggunakan model pembelajaran, adapun dari faktor siswa: masih rendahnya motivasi belajar, sehingga berdampak pada rendahnya hasil belajar. Permasalahan tersebut di atas, dapat dirinci dalam bentuk pertanyaan sebagai berikut :

1. Bagaimanakah kemampuan guru dalam merancang pelaksanaan pembelajaran dengan menerapkan model pembelajaran M2E (Mapping, Matrix and Elaboration) pada pelajaran Alquran-Hadits materi pokok "pengertian hadits, sunah, khobar dan atsar" di Kelas X IPA MAS Argayasa Kabupaten Ciamis?

2. Bagaimanakah proses pelaksanaan pembelajaran dengan menerapkan model pembelajaran M2E (Mapping, Matrix and Elaboration) pada pelajaran Alquran-Hadits materi pokok "pengertian hadits, sunah, khobar dan atsar" di Kelas X IPA MAS Argayasa Kabupaten Ciamis?

3. Apakah pembelajaran dengan menerapkan model pembelajaran M2E (Mapping, Matrix and Elaboration) dapat meningkatkan hasil belajar siswa pada pelajaran Alquran-Hadits materi pokok "pengertian hadits, sunah, khobar dan atsar" di Kelas X IPA MAS Argayasa Kabupaten Ciamis?

\section{Tujuan Pembahasan}

Adapun tujuan penelitian secara khusus yang ingin dicapai adalah sebagai berikut:

1. Untuk mengetahui kemampuan guru dalam merancang pelaksanaan pembelajaran dengan menerapkan model pembelajaran M2E pada pelajaran Alquran-Hadits materi pokok "pengertian hadits, sunah, khobar dan atsar" di Kelas X IPA MAS Argayasa Kabupaten Ciamis.

2. Untuk mengetahui proses pelaksanaan pembelajaran dengan menerapkan model pembelajaran M2E pada pelajaran AlquranHadits materi pokok "pengertian hadits, sunah, khobar dan atsar" di Kelas X IPA MAS Argayasa Kabupaten Ciamis.

3. Untuk mengetahui efektivitas pembelajaran dengan menerapkan model pembelajaran M2E dapat meningkatkan hasil belajar siswa pada pelajaran Alquran-Hadits materi pokok "pengertian hadits, sunah, khobar dan atsar" di Kelas X IPA MAS Argayasa Kabupaten Ciamis.

\section{Metodologi Penelitian}

Dalam tulisan ini menggunakan pendekatan Penelitian Tindakan Kelas (PTK). Subjek penelitian ini adalah guru dan siswa Kelas X IPAMAS Argayasa Kabupaten Ciamis semester genap, yang berjumlah 19 orang siswa, yang terdiri dari 8 orang siswa laki-laki, dan 11 orang siswa perempuan. Objek penelitian adalah penguasaan siswa pada materi, "pengertian hadits, sunah, khobar dan atsar" dengan menerapkan model pembelajaran M2E (Mapping, Matrix and Elaboration). Siklus pelaksanaan penelitian terdiri dari 2 tahap. Masing-masing siklus dilaksanakan pada 2 pertemuan. Setiap pertemuan, guru melaksanakan tindakan perencanaan, pelaksanaan tindakan, observasi dan refleksi.

Data yang dikumpulkan dari saat pratindakan, selama tindakan, maupun sesudah tindakan. Dalam penelitian digunakan 2 cara pengumpulan data yaitu :

1. Teknik Observasi: teknik yang digunakan adalah observasi terstruktur (structured observation) dan tehnik supervisi klinis (clinical supervision). Lembar observasi terstruktur digunakan untuk mengungkapkan partisipasi siswa selama proses pembelajaran, sedangkan lembar supervisi klinis digunakan untuk mengungkapkan aktifitas guru dalam proses pembelajaran.

2. Teknik Tes Tertulis: soal tes ini berupa tes hasil belajar yang berbentuk pilihan ganda yang mencakup soal mudah, sedang dan sukar. Soal tes ini dikerjakan secara individu oleh siswa. Tes digunakan untuk memperoleh gambaran pemahaman hasil belajar siswa setelah ada perubahan aktifitas saat proses pembelajaran pada tiap siklus.

Untuk mempermudah interpretasi data, selanjutnya data-data tersebut diberi identitas yang berdasarkan jenisnya, kemudian divalidasi, sehingga hasilnya sesuai dengan tujuan yang ingin dicapai, dengan digunakannya triangulasi dan number check. Menurut Sugiyono, bahwa 
triangulasi yaitu pengujian kredibilitas data diartikan sebagai pengecekan data dari berbagai sumber dengan berbagai cara, dan berbagai waktu. ${ }^{5}$ Perhitungan hasil observasi dan tes hasil belajar menggunakan teknik persentase. Dengan teknik ini setiap hasil perbaikan pembelajaran ditetapkan dengan batas optimal keberhasilan tindakan yang realistis dan pragmatis.

\section{KERANGKA KONSEPTUAL}

\section{Pengertian Hasil Belajar}

Istilah hasil belajar dapat diartikan sebagai kemampuan yang baru sama sekali atau dapat juga berupa penyempurnaan maupun pengembangan diri suatu kemampuan yang telah dimiliki seseorang yang diperoleh dari proses belajar. ${ }^{6}$ Belajar sangat erat hubungannya dengan prestasi belajar. Karena prestasi itu sendiri merupakan hasil belajar itu biasanya dinyatakan dengan nilai. Menurut Surakhmad, hasil belajar adalah hasil dimana guru melihat bentuk akhir dari pengalaman interaksi edukatif yang diperhatikan adalah menempatkan tingkah laku."7

Hasil belajar siswa adalah produk (output) yang dihasilkan dari proses pembelajaran yang harus dikuasai siswa dalam bentuk : (a) kemahiran intelektual; (b) informasi verbal; (3) mengatur kegiatan intelektual; (d) sikap dan (e) keterampilan motorik. ${ }^{8}$ Dapat diartikan bahwa hasil belajar adalah suatu bentuk pertumbuhan atau perubahan diri seseorang yang dinyatakan dengan cara bertingkah laku baru berkat pengalaman baru. Dalam kaitannya dengan kegiatan belajar, maka hasil belajar merupakan hasil kegiatan belajar sedangkan belajar sendiri lebih menekankan pada proses kegiatannya, selain pada hasil kegiatannya.

Hasil belajar merupakan hasil yang menunjukkan kemampuan seseorang siswa dalam menguasai bahan pelajarannya. Hasil belajar dapat diuji melalui test, sehingga dapat digunakan untuk mengetahui keefektifan pengajaran dan keberhasilan siswa atau guru dalam proses belajar mengajar. Hasil belajar yaitu bentuk tingkah laku

\footnotetext{
${ }^{5}$ Sugiyono, Statistika Untuk Penelitian (Bandung: Alfabeta, 2005), 77.

${ }^{6}$ W.S. Winkel, Psikologi Pendidikan (Jakarta: Rineka Cipta, 2006), 38.

${ }^{7}$ Winarno Surakhmad, Pengantar Dan Teknik Penelitian Ilmiah (Bandung: Tarsito, 2008), 88.

${ }^{8}$ Nana Sudjana, Dasar-Dasar Proses Belajar Mengajar (Bandung: Sinar Baru Algesindo, 2010), 55.

9 Anthony Anggrawan, "Analisis Deskriptif Hasil Belajar Pembelajaran Tatap Muka dan Pembelajaran Daring
}

pekerjan bertingkat yang dimiliki siswa setelah menyelesaikan pengalaman belajar. Bentuk tingkah laku sebagai hasil belajar dapat berupa memberi reaksi terhadap rangsangan, asosiasi verbal, mengemukakan konsep, prinsip dan memecahkan masalah. ${ }^{9}$ Hasil belajar biasanya diperoleh setelah siswa dinyatakan berhasil dalam suatu penilaian yang dilaksanakan pada bagian akhir pmbelajaran. Oleh karena itu hasil belajar siswa disekolah dipengaruhi oleh kemampuan siswa dan kualitas pembelajaran.

Menurut Dick dan Reiser bahwa hasil belajar merupakan kemampuan yang dimiliki siswa sebagai hasil kegiatan pembelajaran. ${ }^{10}$ Lebih lanjut mereka membedakan hasil belajar menjadi empat macam yaitu pengetahuan, ketrampilan intelektual, keterampilan motorik dan sikap. Untuk mengetahui hasil belajar yang dicapai siswa maka diadakan penilaian. Penilaian dapat dilaksanakan setiap saat selama kegiatan berlangsung, dapat juga diadakan setelah siswa menyelesaikan suatu program pembelajaran dalam waktu tertentu misalnya setelah satu pokok bahasan atau satu semester. Penilaian terhadap hasil belajar menggunakan alat ukur berupa tes.

Hasil belajar siswa merupakan perpaduan dari pengetahuan, keterampilan, nilai dan sikap yang direfleksikan dalam kebiasaan berpikir dan bertindak. ${ }^{11}$ Sedangkan prestasi belajar siswa dapat diartikan sebagai pengetahuan, keterampilan dan kemampuan yang dikuasai oleh seseorang yang telah menjadi bagian dari dirinya, sehingga dapat melakukan perilaku-perilaku kognitif, afektif, dan psikomotorik dengan sebaikbaiknya.

Hasil belajar siswa menurut Syah meliputi : (1) ranah kognitif meliputi: pengamatan, ingatan, pemahaman, penerapan, analisis dan sistesis; (2)ranah afektif meliputi: penerimaan, sambutan, apresiasi, internalisasi, dan karakterisasi; dan (3) ranah psikomotor meliputi: keterampilan bergerak dan kecakapan ekspresi verbal dan nonverbal. ${ }^{12}$ Sedangkan prestasi belajar siswa adalah produk (output) yang dihasilkan dari proses pembelajaran yang harus dikuasai siswa dalam

Menurut Gaya Belajar Mahasiswa," Jurnal Matrik 18, no. 2 (2019): 339-46.

${ }^{10}$ Syaiful Bahri Djamarah and Sopian, Psikologi Belajar

(Jakarta: Rineka Cipta, 2012), 30.

11 E Mulyasa, Menjadi Guru Profesional (Menciptakan Pembelajaran Kreatif Dan Menyenangkan) (Bandung: Remaja Rosdakarya, 2016), 37.

12 Muhibbin Syah, Psikologi Pendidikan Dengan Suatu

Pendekatan Baru (Bandung: Remaja Rosdakarya, 2010), 171. 
bentuk : (a) kemahiran intelektual; (b) informasi verbal; (3) mengatur kegiatan intelektual; (d) sikap dan (e) keterampilan motorik. ${ }^{13}$ Prestasi belajar adalah segenap ranah psikologis yang mengalami perubahan sebagai akibat pengalaman dan proses belajar. ${ }^{14}$ Sedangkan menurut Bloom bahwa hasil belajar dibedakan menjadi tiga aspek yaitu kognitif, afektif dan psikomotorik. ${ }^{15}$

\section{Pembelajaran Alquran-Hadits}

Mata pelajaran Alquran-Hadits di Madrasah Tsanawiyah dan Aliyah adalah salah satu mata pelajaran pendidikan agama Islam yang merupakan peningkatan dari Alquran-Hadits yang telah dipelajari oleh peserta didik di Madrasah Ibtidaiyah - Madrasah Aliyah. Peningkatan tersebut dilakukan dengan cara mempelajari, memperdalam serta memperkaya kajian Alquran dan haditsterutama menyangkut dasar-dasar keilmuannya sebagai persiapan untuk melanjutkan ke pendidikan menengah, serta memahami dan menerapkan tema-tema tentang manusia dan tanggung jawabnya di muka bumi, demokrasi serta pengembangan ilmu pengetahuan dan teknologi dalam perspektif Alquran dan haditssebagai persiapan untuk hidup bermasyarakat.

Secara substansial, mata pelajaran AlquranHadits memiliki kontribusi dalam memberikan motivasi kepada peserta didik untuk mempelajari dan mempraktikkan ajaran dan nilai-nilai yang terkandung dalam Alquran-hadits sebagai sumber utama ajaran Islam dan sekaligus menjadi pegangan dan pedoman hidup dalam kehidupan sehari-hari. Mata pelajaran Alquran-Hadits mempunyai tujuan yakni meningkatkan kecintaan peserta didik terhadap Alquran dan Hadits serta membekali peserta didik dengan dalil-dalil yang terdapat dalam Alquran dan hadits sebagai pedoman dalam menyikapi dan menghadapi kehidupan. Selain itu juga meningkatkan pemahaman dan pengamalan isi kandungan Alquran dan Hadits yang dilandasi oleh dasardasar keilmuan tentang Alquran dan Hadits. ${ }^{16}$

\section{Penggunaan Model Pembelajaran M2E (Mapping, Matrix and Elaboration)}

Penggunaan strategi pembelajaran yang baik dan menarik yang mampu meningkatkan

\footnotetext{
${ }^{13}$ Nana Sudjana, Dasar-Dasar Proses Belajar Mengajar (Bandung: Sinar Baru Algesindo, 2010), 55.

${ }^{14}$ Muhibbin Syah, Psikologi Pendidikan Dengan Suatu Pendekatan Baru (Bandung: Remaja Rosdakarya, 2010), 150.

15 Suharsimi Arikunto, Penelitian Tindakan Kelas (Jakarta: Bumi Aksara, 2010), 110.
}

hasil belajar siswa dalam proses pembelajaran pada pembelajaran Alquran-Hadits materi pokok "Pengertian hadits, sunah, khobar dan atsar" sangat diperlukan. Salah satu upayanya yaitu dengan menggunakan Model pembelajaran M2E (Mapping, Matrix and Elaboration). Model pembelajaran M2E (Mapping, Matrix and Elaboration) memiliki sintaks: informasi kompetensi, sajian permasalahan terbuka, siswa berkelompok untuk menanggapi dan membuat berbagai alternatiu jawababan, presentasi hasuil diskusi kelompok, siswa membuat kesimpulan dari hasil setiap kelompok, evaluasi dan refleksi.

Model pembelajaran ini memiliki manfaat antara lain (1) pembelajaran akan lebih menarik perhatian siswa sehingga diharapkan dapat menumbuhkan motivasi belajar siswa, (2) materi pembelajaran lebih jelas maknannya sehingga siswa lebih menudah memahami, (3) metodologi pembelajaran lebih bervariasi, dan (4) pembelajaran terfokus kepada siswa dengan melakukan berbagai aktivitas.

Penggunaan model pembelajaran yang baik dan menarik yang mampu meningkatkan hasil belajar siswa dalam proses pembelajaran AlquranHadits sangat diperlukan. Model pembelajaran merupakan kerangka konseptual yang menggambarkan prosedur yang sistematis dalam mengorganisasikan pengalaman belajar untuk mencapai tujuan belajar tertentu. Fungsi dari strategi pembelajaran adalah sebagai pedoman bagi guru dalam merencanakan dan melaksanakan proses pembelajaran. ${ }^{17}$

\section{HASIL DAN PEMBAHASAN}

\section{Siklus I}

Pada awal kegiatan pembelajaran berlangsung sebagian besar siswa cenderung kurang berminat menyelesaikan tugas yang diberikan oleh guru, dan guru harus selalu mengingatkan agar siswa mampu membuat pertanyaan pada materi pokok "pengertian hadits, sunah, khobar dan atsar," siswa kurang memperhatikan penjelasan guru, kurang bersemangat dan cenderung pasif, tidak aktif dalam mengemukakan pendapat atau bertanya dalam mengikuti proses pembelajaran.

\footnotetext{
${ }^{16}$ Mardhiyah, M. Dahlan R, and Tjetjep Suhandi, "Strategi Guru Dalam Meningkatkan Motivasi Belajar Peserta Didik Pada Mata Pelajaran Al-Qur'an Dan Hadits," Fikrab: Journal Of Islamic Education 2, no. 1 (2018): 1-12.

17 Trianto, Mendesain Strategi Pembelajaran Inovatif Progresif (Jakarta: Prenadamedia Group, 2007), 44.
} 
Minat belajar siswa dalam pembelajaran kurang ditandai dengan banyaknya siswa selama proses pembelajaran berlangsung tidak ada minat untuk membuat pertanyaan berkaitan dengan materi pokok "pengertian hadits, sunah, khobar dan atsar." Minat untuk bertanya juga kurang karena siswa cenderung pasif pada saat guru memberikan tugas menggunakan Model pembelajaran M2E. Hal tersebut berpengaruh terhadap skor post-test atau hasil belajar pada materi pokok "pengertian hadits, sunah, khobar dan atsar" pada siklus I dengan menggunakan Model pembelajaran M2E pada siklus I di Kelas X IPA MAS Argayasa Kabupaten Ciamis dapat diketahui bahwa rata-rata nilainya sebesar 71,05. Dari rata-rata nilai tersebut, siswa yang mendapat nilai 60 sebanyak 3 orang, yang mendapat nilai 70 sebanyak 11 orang, dan yang mendapatkan nilai 80 sebanyak 5 orang.

Untuk mengetahui hasil belajar siswa di Kelas X IPA MAS Argayasa Kabupaten Ciamis pada pelajaran Alquran-Hadits pada materi pokok "pengertian hadits, sunah, khobar dan atsar" dengan menggunakan Model pembelajaran M2E pada siklus I dapat diketahui sebagai berikut:

\begin{tabular}{|c|l|c|c|}
\hline $\begin{array}{c}\text { No } \\
.\end{array}$ & Kategorisasi & $\begin{array}{c}\text { Jumlah } \\
\text { siswa }\end{array}$ & $\begin{array}{c}\text { Prosenta } \\
\text { se (\%) }\end{array}$ \\
\hline 1. & $\begin{array}{l}\text { Siswa yang } \\
\text { sudah tuntas }(\geq \\
75)\end{array}$ & 5 & $24 \%$ \\
\hline 2. & $\begin{array}{l}\text { Siswa yang } \\
\text { belum tuntas }(< \\
75)\end{array}$ & 14 & $76 \%$ \\
\hline & \multicolumn{1}{|c|}{ Jumlah } & 19 & $100 \%$ \\
\hline
\end{tabular}

Tabel 1: Hasil Belajar Siswa

Dengan demikian diketahui bahwa hasil belajar siswa pada siklus I memiliki rata-rata nilai 71,05 dan pada siklus I yang tuntas ada 5 orang $(24 \%)$ dan yang belum tuntas ada 14 orang $(76 \%)$.

Berdasarkan hasil penelitian tindakan kelas pada pembelajaran Alquran-Hadits di Kelas X IPAMAS Argayasa Kabupaten Ciamis pada pelajaran Alquran-Hadits pada "Pengertian hadits, sunah, khobar dan atsar" dengan menggunakan model pembelajaran M2E pada siklus I. Penelitian ini dilakukan oleh peneliti sebagai guru mata pelajaran Alquran-Hadits kelas IX, dan berkolaborasi dengan guru mata pelajaran Alquran-Hadits kelas VII sekaligus sebagai observer. Hasil observasi terhadap kemampuan guru merancang RPP, aktivitas guru dalam proses pembelajaran dan aktivitas belajar siswa pada siklus I dapat diuraikan sebagai berikut :

\section{Hasil Observasi}

Berdasarkan tabel pada lampiran 4A diketahui bahwa kemampuan guru dalam merancang Rencana Pelaksanaan Pembelajaran pada siklus I diketahui hasil observasi kemampuan guru dalam dalam menyusun rencana pembelajaran pada siklus I diperoleh bahwa guru masih belum optimal dalam merancang RPP karena masih terdapat aspekaspek tertentu belum dicapai oleh guru. Adapun hasil yang dicapai guru dalam menyusun rencana pembelajaran pada siklus I ini yaitu: (1) aspek kurikulum memperoleh nilai maksimal dengan rata-rata $65 \%$; (2) aspek mengembangkan dan mengorganisasikan materi, media nilai rata-rata yang dicapai $60 \%$; (3) aspek merancang skenario pembelajaran nilai rata-rata $60 \%$; (4) aspek perumusan dan pencapaian tujuan pembelajaran nilai rata-rata $60 \%$; (5) aspek evaluasi rata-rata $65 \%$; (6) aspek lampiran rata-rata yang dicapai $65 \%$; dan (7) aspek kerapihan mendapat nilai kurang dengan rata-rata $65 \%$.

Dilihat dari nilai rata-rata yang diperoleh pada siklus I, kemampuan guru dalam merancang rencana pembelajaran belum mencapai kriteria berhasil sebagaimana yang telah ditetapkan. Untuk itu indikator-indikator yang belum dicapai perlu diperbaiki pada tindakan kedua. Rata-rata yang dicapai kemampuan guru dalam membuat Rencana Pelaksanaan Pembelajaran pada siklus I sebesar $62,14 \%$ taraf ini sudah menujukan kategori baik namun masih bisa ditingkatkan.

\section{Hasil Observasi}

Dari tabel pada lampiran 5A diketahui bahwa pelaksanaan pembelajaran oleh guru pada siklus I menunjukkan bahwa guru belum optimal dalam melaksanakan pembelajaran karena terdapat beberapa indikator-indikator tertentu yang belum dicapai secara baik oleh guru yaitu: melaksanakan persepsi yang bermakna, membangkitkan motivasi siswa untuk belajar tentang materi pembelajaran, memberi petunjuk dan penjelasan yang berkaitan dengan pelaksanaan pembelajaran, penanganan individual atau siswa dilakukan dengan efektif dan wajar, memicu dan memelihara keterlibatan siswa, memantapkan penguasaan materi pembelajaran, membangun dan mengembangkan hubungan antar pribadi yang sehat dan sehat, membantu siswa menyadari kelebihan dan kekurangannya serta membantu menumbuhkan rasa percaya diri dan menata kembali kerapihan atau suasana kelas 
agar kondusif bagi kegiatan pembelajaran berikutnya.

Setelah dicermati ternyata aspek proses pelaksanaan pembelajaran oleh guru sangat memerlukan perbaikan pada siklus berikutnya adalah kemampuan guru memanfaatkan alat peraga dan mengefektifkan pelaksanaan Model pembelajaran M2E pada kegiatan awal dan kegiatan akhir pembelajaran terutama dalam hal: (1)proses pembelajaran, (2) kemampuan mengkonstruksi, (3) evaluasi, dan (4)menutup pelajaran. Keempat aspek ini sama sekali belum tersentuh secara sengaja oleh guru.

Adapun hasil yang dicapai oleh guru pada setiap aspek dalam melaksanakan pembelajaran pada siklus I yaitu : (1) kegiatan Pra PBM mendapat nilai rata-rata $65 \%$, (2) kemampuan membuka pelajaran mendapat nilai rata-rata $66 \%$, (3) sikap guru dalam PBM mendapat nilai $60 \%$, (4) penguasaan bahan ajar mendapat nila 68\%, (5) proses pembelajaran memperoleh nilai $60 \%$, (6)kemampuan mengkonstruksi pengetahuan dalam pembelajaran memperoleh nilai $55 \%$, (7) kemampuan menggunakan alat peraga pembelajaran mendapat nilai $60 \%$, (8) evaluasi mendapat nilai $60 \%$, dan (9) kemampuan menutup pelajaran mendapat nilai $60 \%$.

Dengan demikian, rata-rata yang dicapai kemampuan guru dalam melaksanakan proses pembelajaran adalah 61,5\%. Taraf ini menunjukkan kategori sangat baik namun masih dapat ditingkatkan. Berdasarkan data tersebut, pelaksanaan pembelajaran pada siklus I perlu ditingkatkan lagi terutama dalam hal penguasaan materi pembelajaran dan penguasaan kelas sehingga waktu yang digunakan lebih efisien.

\section{Hasil Observasi}

Berdasarkan tabel pada lampiran 6A diketahui bahwa penilaian aktivitas belajar siswa pada siklus I, dapat disimpulkan bahwa aktivitas belajar siswa pada siklus I adalah cukup. Hal ini dibuktikan dari prosentase jumlah nilai hasil penilaian aktivitas belajar siswa adalah sebesar 65\%. Standar keberhasilan minimal 75\% belum tercapai, sehingga masih perlu ditingkatkan pada pelaksanaan siklus berikutnya.

Hasil observasi kemampuan guru merancang RPP, aktivitas guru dalam proses pembelajaran dan aktivitas belajar siswa pada siklus I dapat disusun dalam bentuk rekapitulasi pada tabel di bawah ini.

\begin{tabular}{|c|l|c|}
\hline No. & \multicolumn{1}{|c|}{$\begin{array}{c}\text { Aspek yang } \\
\text { Diobservasi }\end{array}$} & Persentase \\
\hline 1 & $\begin{array}{l}\text { Kemampuan Guru } \\
\text { dalam merancang RPP }\end{array}$ & $62,14 \%$ \\
\hline 2 & $\begin{array}{l}\text { Aktivitas guru dalam } \\
\text { pembelajaran }\end{array}$ & $61,5 \%$ \\
\hline 3 & $\begin{array}{c}\text { Akltivitas belajar Siswa } \\
\text { Rata-rata }\end{array}$ & $65 \%$ \\
\hline \multicolumn{2}{|c|}{$62,88 \%$} \\
\hline
\end{tabular}

Tabel 1: Rekapitulasi Hasil Observasi

Berdasarkan hasil belajar siswa, serta hasil observasi terhadap kemampuan guru merancang RPP, aktivitas guru dalam proses pembelajaran dan aktivitas belajar siswa pada pembelajaran Alquran-Hadits di Kelas X IPAMAS Argayasa Kabupaten Ciamis pada pelajaran Alquran-Hadits pada "Pengertian hadits, sunah, khobar dan atsar" dengan menggunakan Model pembelajaran M2E pada siklus I dapat dilakukan evaluasi dan refleksi berikut ini:

Berdasarkan observasi dan temuan data hasil belajar pada siklus I, secara umum guru telah menyelenggarakan pembelajaran dengan menggunakan Model pembelajaran M2E sesuai dengan yang direncanakan, namun hasil belajar belum memenuhi target, maka peneliti bersama observer melakukan refleksi tindakan yang harus diperbaiki pada siklus I. Refleksi pembelajaran siklus I dapat dilihat pada tabel berikut ini.

\begin{tabular}{|c|c|c|c|}
\hline $\begin{array}{l}\mathbf{N} \\
\mathbf{o}\end{array}$ & $\begin{array}{c}\text { Kesulitan } \\
\text { Guru }\end{array}$ & $\begin{array}{l}\text { Kesulitan } \\
\text { Siswa }\end{array}$ & $\begin{array}{c}\text { Saran/Per } \\
\text { baikan }\end{array}$ \\
\hline 1. & $\begin{array}{l}\text { Penguasaa } \\
\text { n materi } \\
\text { belum } \\
\text { maksimal }\end{array}$ & $\begin{array}{l}\text { Kemampua } \\
\mathrm{n} \\
\text { menghubun } \\
\text { gkan fakta } \\
\text { kurang } \\
\text { terarah } \\
\text { sehingga } \\
\text { pemahaman } \\
\text { terhadap } \\
\text { materi } \\
\text { masih } \\
\text { rendah }\end{array}$ & $\begin{array}{l}\text { Penguasaan } \\
\text { materi guru } \\
\text { harus lebih } \\
\text { ditingkatkan } \\
\text { dan } \\
\text { mengintensi } \\
\text { fkan } \\
\text { bimbingan } \\
\text { bagi siswa } \\
\text { yang lamban } \\
\text { dalam } \\
\text { memahami } \\
\text { materi. }\end{array}$ \\
\hline 2. & $\begin{array}{l}\text { Guru } \\
\text { tampak } \\
\text { ragu pada } \\
\text { saat } \\
\text { memberik } \\
\text { an } \\
\text { penjelasan } \\
\text { tentang } \\
\text { penggunaa } \\
\text { n strategi }\end{array}$ & $\begin{array}{l}\text { Beberapa } \\
\text { siswa masih } \\
\text { bingung } \\
\text { menggunak } \\
\text { an Model } \\
\text { pembelajara } \\
\text { n M2E dan } \\
\text { menunggu } \\
\text { perintah } \\
\text { dari guru }\end{array}$ & $\begin{array}{l}\text { Guru harus } \\
\text { lebih } \\
\text { meninngkat } \\
\text { kan } \\
\text { penjelasan } \\
\text { tentang } \\
\text { penggunaan } \\
\text { Model } \\
\text { pembelajara } \\
\text { n M2E. }\end{array}$ \\
\hline
\end{tabular}




\begin{tabular}{|c|c|c|c|}
\hline & $\begin{array}{l}\text { pembelaja } \\
\text { ran }\end{array}$ & $\begin{array}{l}\text { dalam } \\
\text { melaksanak } \\
\text { an } \\
\text { pembelajara } \\
\text { n. }\end{array}$ & \\
\hline 3. & $\begin{array}{l}\text { Guru } \\
\text { tampak } \\
\text { kurang } \\
\text { lancar } \\
\text { dalam } \\
\text { melakukan } \\
\text { tanya } \\
\text { jawab, } \\
\text { sehingga } \\
\text { kurang } \\
\text { terjadi } \\
\text { interaksi } \\
\text { antara } \\
\text { guru dan } \\
\text { siswa pasif } \\
\text { terutama } \\
\text { pada saat } \\
\text { penjelasan } \\
\text { materi. }\end{array}$ & $\begin{array}{l}\text { Siswa sulit } \\
\text { memusatka } \\
\mathrm{n} \text { perhatian } \\
\text { dan kurang } \\
\text { memahami } \\
\text { materi yang } \\
\text { disampaikan } \\
\text {, sehingga } \\
\text { pada saat } \\
\text { menggunak } \\
\text { an Model } \\
\text { pembelajara } \\
\text { n M2E } \\
\text { kebingunga } \\
n \text { pada saat } \\
\text { menerima } \\
\text { tugas dari } \\
\text { guru }\end{array}$ & $\begin{array}{l}\text { Guru harus } \\
\text { meningkatk } \\
\text { an motivasi } \\
\text { pada siswa } \\
\text { dengan } \\
\text { tidak } \\
\text { mendomina } \\
\text { si dan } \\
\text { pembelajara } \\
\text { n meningkatk } \\
\text { an motivasi } \\
\text { untuk lebih } \\
\text { aktif pada } \\
\text { pembelajara } \\
\text { n dan saling } \\
\text { membantu }\end{array}$ \\
\hline 4. & $\begin{array}{l}\text { Kesulitan } \\
\text { dalam } \\
\text { mengopti } \\
\text { malkan } \\
\text { interaksi } \\
\text { sosial } \\
\text { dalam } \\
\text { melaksana } \\
\text { kan } \\
\text { pembelaja } \\
\text { ran } \\
\text { melalui } \\
\text { Model } \\
\text { pembelaja } \\
\text { ran M2E }\end{array}$ & $\begin{array}{l}\text { Siswa hanya } \\
\text { mengetahui } \\
\text { konsep dari } \\
\text { buku teks } \\
\text { yang mereka } \\
\text { pegang }\end{array}$ & $\begin{array}{l}\text { Guru } \\
\text { mengoptim } \\
\text { alkan tanya } \\
\text { jawab } \\
\text { tentang isi } \\
\text { materi } \\
\text { dengan } \\
\text { menggunak } \\
\text { an Model } \\
\text { pembelajara } \\
\text { n M2E }\end{array}$ \\
\hline 5. & $\begin{array}{l}\text { Waktu } \\
\text { Pembelaja } \\
\text { ran tidak } \\
\text { sesuai } \\
\text { dengan } \\
\text { waktu } \\
\text { yang telah } \\
\text { direncana } \\
\text { kan. }\end{array}$ & $\begin{array}{l}\text { Beberapa } \\
\text { siswa masih } \\
\text { ada } \\
\text { kecenderun } \\
\text { gan bersikap } \\
\text { acuh, dan } \\
\text { tidak } \\
\text { membantu } \\
\text { temannya. }\end{array}$ & $\begin{array}{l}\text { Guru } \\
\text { memotivasi } \\
\text { siswa akan } \\
\text { pentingnya } \\
\text { bekerja } \\
\text { sama. }\end{array}$ \\
\hline
\end{tabular}

Tabel 1: Hasil Refleksi Siklus I

Hasil refleksi pembelajaran siklus I tersebut dapat dijadikan sebagai rekomendasi untuk pembelajaran siklus II.

\section{Siklus II}

Pada siklus II, selama kegiatan pembelajaran mulai dari awal kegiatan hingga akhir kegiatan siswa mulai tampak aktif, tidak ragu-ragu dalam melaksanakan tugas dari guru dan terjalin komunikasi antarsiswa karena setiap siswa telah memahami apa yang harus dikerjakan dalam menggunakan model pembelajaran M2E pada materi pokok "pengertian hadits, sunah, khobar dan atsar."

Suasana kelas pada siklus II ini lebih hidup. Pada saat kegiatan pembelajaran, siswa mulai aktif melakukan kegiatan pembelajaran dalam membuat pertanyaan pada kelompoknya masingmasing. Terdapat beberapa orang siswa sudah memahami apa yang harus dilakukan. Siswa berani dalam melaksanakan kegiatan pembelajaran secara tepat dan benar. Hal tersebut berpengaruh terhadap skor post-test atau hasil belajar pada materi pokok "Pengertian hadits, sunah, khobar dan atsar" dengan menggunakan Model pembelajaran M2E pada siklus II di Kelas X IPAMAS Argayasa Kabupaten Ciamis dapat diketahui bahwa rata-rata nilainya sebesar 80,53. Dari rata-rata nilai tersebut, siswa yang mendapat nilai 70 sebanyak 3 orang, dan yang mendapat nilai 80 sebanyak 12 orang dan nilai 90 ada 4 orang.

Untuk mengetahui hasil belajar siswa di Kelas X IPAMAS Argayasa Kabupaten Ciamis pada pelajaran Alquran-Hadits pada materi pokok "pengertian hadits, sunah, khobar dan atsar" dengan menggunakan Model pembelajaran M2E pada siklus II dapat diketahui sebagai berikut:

\begin{tabular}{|c|c|c|c|}
\hline No. & Kategorisasi & $\begin{array}{c}\text { Jumlah } \\
\text { siswa }\end{array}$ & $\begin{array}{c}\text { Persentase } \\
(\%)\end{array}$ \\
\hline 1. & $\begin{array}{l}\text { Siswa yang } \\
\text { sudah tuntas } \\
(\geq 75)\end{array}$ & 16 & $84 \%$ \\
\hline 2. & $\begin{array}{l}\text { Siswa yang } \\
\text { belum tuntas } \\
(<75)\end{array}$ & 3 & $16 \%$ \\
\hline & Jumlah & 19 & $100 \%$ \\
\hline
\end{tabular}

Tabel 3: Hasil Belajar Siswa

Berdasarkan pengamatan, siswa dalam pembelajaran pada siklus II hasil belajarnya memiliki rata-rata nilai 80,53 dan pada siklus II yang tuntas sebanyak 16 orang $(84 \%)$ dan yang belum tuntas hasil belajarnya sebanyak 3 orang $(16 \%)$.

Hasil observasi penelitian tindakan kelas pada pembelajaran Alquran-Hadits di Kelas X 
IPA MAS Argayasa Kabupaten Ciamis pada pelajaran Alquran-Hadits pada "pengertian hadits, sunah, khobar dan atsar" dengan menggunakan model pembelajaran M2E yang dilakukan oleh peneliti yang berkolaborasi dengan guru mata pelajaran Alquran-Hadits kelas VII sekaligus sebagai observer tentang kemampuan guru dalam merancang RPP, aktivitas guru dalam proses pembelajaran, dan aktivitas belajar siswa pada siklus II dapat diuraikan sebagaimana berikut di bawah.

1. Hasil Observasi Kemampuan Guru dalam Merancang RPP

Dapat diketahui bahwa kemampuan guru dalam menyusun rencana pembelajaran pada siklus II menunjukkan bahwa kemampuan guru sudah optimal, indikator-indikator obsevasi menunjukkan nilai baik. Hal tersebut menunjukkan adanya perubahan dan peningkatan yang lebih baik dari siklus pertama. aspek-aspek yang sudah dicapai oleh guru pada siklus kedua, yaitu: aspek kurikulum mendapat nilai $80 \%$ aspek mengembangkan dan mengorganisasikan materi, media dan sumber belajar mendapat nilai $80 \%$, aspek merancang skenario kegiatan pembelajaran mendapat nilai $76 \%$, aspek perumusan pencapaian tujuan pembelajaran mencapai nilai $80 \%$, aspek evaluasi mendapat nilai $80 \%$, dan aspek lampiran mendapat nilai $80 \%$ dan yang terakhir aspek kerapian RPP mendapat nilai 80\%.

Kemampuan guru dalam membuat rencana pelaksanaan pembelajaran pada siklus kedua secara keseluruhan memperoleh nilai ratarata $80 \%$, telah mencapai keberhasilan. Dengan demikian kemampuan guru pada siklus kedua ini sudah mencapai taraf penguasaan tuntas karena telah melampaui target pencapaian keberhasilan yang sudah ditetapkan yaitu minimal $75 \%$.

\section{Hasil Observasi Aktivitas Guru dalam Proses Pembelajaran}

Dapat diketahui bhawa pelaksanaan pembelajaran oleh guru pada siklus II menunjukkan bahwa guru sudah optimal. Hal ini dapat dilihat dari aspek-aspek yang diobservasi sudah memperoleh nilai baik. Adapun hasil yang dicapai oleh guru pada setiap aspek dalam melaksanakan pembelajaran pada siklus II yaitu : (1) kegiatan Pra PBM mendapat nilai rata-rata $90 \%$, (2) kemampuan membuka pelajaran mendapat nilai rata-rata $90 \%$, (3) sikap guru dalam PBM mendapat nilai $85 \%$, (4) penguasaan bahan ajar mendapat nila $80 \%$, (5) proses pembelajaran memperoleh nilai $75 \%$, (6)kemampuan mengkonstruksi pengetahuan dalam pembelajaran memperoleh nilai $75 \%$, (7) kemampuan menggunakan alat peraga pembelajaran mendapat nilai $70 \%$, (8) evaluasi mendapat nilai $70 \%$, dan (9) kemampuan menutup pelajaran mendapat nilai $72 \%$.

Dengan demikian, rata-rata yang dicapai kemampuan guru dalam melaksanakan proses pembelajaran adalah 78\%. Dengan demikian aktivitas guru pada siklus II sudah mencapai mencapai penguasaan tuntas karena telah melampaui target penguasaan yang telah ditentukan yaitu $75 \%$.

\section{Hasil Observasi Aktivitas Belajar Siswa}

Dapat diketahui bahwa penilaian aktivitas belajar siswa pada siklus II, dapat disimpulkan bahwa aktivitas belajar siswa pada siklus II adalah sangat baik. Hal ini dibuktikan dari prosentase jumlah nilai hasil penilaian aktivitas belajar siswa adalah sebesar $80 \%$. Standar keberhasilan minimal $75 \%$ sudah tercapai, sehingga pelaksanaan siklus II sudah tuntas.

Hasil observasi kemampuan guru merancang RPP, aktivitas guru dalam proses pembelajaran dan aktivitas belajar siswa pada siklus II dapat disusun dalam bentuk rekapitulasi pada tabel di bawah ini.

\begin{tabular}{|c|c|c|}
\hline No. & $\begin{array}{l}\text { Aspek yang } \\
\text { Diobservasi }\end{array}$ & Prosentase \\
\hline 1 & \begin{tabular}{lr}
\multicolumn{2}{l}{ Kemampuan guru } \\
dalam merancang \\
RPP
\end{tabular} & $80 \%$ \\
\hline 2 & $\begin{array}{l}\text { Aktivitas guru dalam } \\
\text { pembelajaran }\end{array}$ & $78 \%$ \\
\hline 3 & $\begin{array}{l}\text { Akltivitas belajar } \\
\text { Siswa }\end{array}$ & $80 \%$ \\
\hline \multicolumn{2}{|r|}{ Rata-rata } & $79,33 \%$ \\
\hline
\end{tabular}

Tabel 4 Rekapitulasi Hasil Observasi Siklus II

Berdasarkan observasi dan temuan data hasil belajar pada siklus II, secara umum guru telah menyelenggarakan pembelajaran dengan menggunkan model pembelajaran M2E sesuai dengan yang direncanakan, namun hasil belajar belum memenuhi target sehingga peneliti bersama observer melakukan refleksi tindakan yang harus diperbaiki pada siklus II. Refleksi pembelajaran siklus II dapat dilihat pada tabel berikut ini.

\begin{tabular}{|l|l|l|l|}
\hline $\begin{array}{l}\text { N } \\
\text { o }\end{array}$ & Kesulitan & Kesulitan & $\begin{array}{l}\text { Saran/Perba } \\
\text { ikan }\end{array}$ \\
\hline 1. & $\begin{array}{l}\text { Penguasaa } \\
\text { Siswa }\end{array}$ & $\begin{array}{l}\text { Kemampu } \\
\text { n guru }\end{array}$ & $\begin{array}{l}\text { Penguasaan } \\
\text { an }\end{array}$ \\
& $\begin{array}{l}\text { materi guru } \\
\text { terhadap }\end{array}$ & menghubu & sudah intensif \\
\hline
\end{tabular}




\begin{tabular}{|c|c|c|c|}
\hline & $\begin{array}{l}\text { materi } \\
\text { sudah } \\
\text { maksimal }\end{array}$ & $\begin{array}{l}\text { ngkan } \\
\text { fakta } \\
\text { sudah } \\
\text { lebih } \\
\text { terarah } \\
\text { sehingga } \\
\text { pemaham } \\
\text { an } \\
\text { terhadap } \\
\text { materi } \\
\text { sudah } \\
\text { lebih baik }\end{array}$ & $\begin{array}{l}\text { dalam } \\
\text { memberi } \\
\text { bimbingan } \\
\text { bagi siswa } \\
\text { yang lamban } \\
\text { dalam } \\
\text { memahami } \\
\text { materi. }\end{array}$ \\
\hline 2. & $\begin{array}{l}\text { Guru tidak } \\
\text { ragu-ragu } \\
\text { pada saat } \\
\text { memberik } \\
\text { an } \\
\text { penjelasan } \\
\text { tentang } \\
\text { penggunaa } \\
\text { n strategi } \\
\text { pembelaja } \\
\text { ran }\end{array}$ & $\begin{array}{l}\text { Sebagian } \\
\text { kecil siswa } \\
\text { masih } \\
\text { bingung } \\
\text { mengguna } \\
\text { kan Model } \\
\text { pembelaja } \\
\text { ran M2E } \\
\text { dan } \\
\text { menunggu } \\
\text { perintah } \\
\text { dari guru } \\
\text { dalam } \\
\text { melaksana } \\
\text { kan } \\
\text { pembelaja } \\
\text { ran. }\end{array}$ & $\begin{array}{l}\text { Guru harus } \\
\text { lebih } \\
\text { meninngkatka } \\
\text { n penjelasan } \\
\text { tentang } \\
\text { penggunaan } \\
\text { Model } \\
\text { pembelajaran } \\
\text { M2E. }\end{array}$ \\
\hline 3. & \begin{tabular}{l} 
Guru \\
sudah \\
lebih \\
lancar \\
dalam \\
melakukan \\
tanya \\
jawab, \\
sehingga \\
kurang \\
terjadi \\
interaksi \\
antara \\
guru dan \\
siswa tidak \\
pasif lagi \\
\multicolumn{1}{c}{ teruta } \\
ma pada \\
saat \\
penjelasan \\
materi.
\end{tabular} & $\begin{array}{l}\text { Sebagian } \\
\text { kecil siswa } \\
\text { sulit } \\
\text { memusatk } \\
\text { an } \\
\text { perhatian } \\
\text { dan } \\
\text { kurang } \\
\text { memaham } \\
\text { i materi } \\
\text { yang } \\
\text { disampaik } \\
\text { an, } \\
\text { sehingga } \\
\text { pada saat } \\
\text { mengguna } \\
\text { kan Model } \\
\text { pembelaja } \\
\text { ran M2E } \\
\text { kebingung } \\
\text { an dan } \\
\text { masih } \\
\text { perlu } \\
\text { bimbingan } \\
\text { guru }\end{array}$ & $\begin{array}{l}\text { Guru harus } \\
\text { meningkatkan } \\
\text { motivasi pada } \\
\text { siswa agar } \\
\text { tidak } \\
\text { mendominasi } \\
\text { pembelajaran } \\
\text { dan serta } \\
\text { lebih } \\
\text { meningkatkan } \\
\text { motivasi } \\
\text { untuk lebih } \\
\text { aktif pada } \\
\text { pembelajaran }\end{array}$ \\
\hline 4. & $\begin{array}{l}\text { Sudah } \\
\text { mampu }\end{array}$ & $\begin{array}{l}\text { Siswa } \\
\text { bukan saja }\end{array}$ & $\begin{array}{l}\text { Guru lebih } \\
\text { mengoptimal }\end{array}$ \\
\hline
\end{tabular}

\begin{tabular}{|c|c|c|c|}
\hline & $\begin{array}{l}\text { mengopti } \\
\text { malkan } \\
\text { interaksi } \\
\text { sosial } \\
\text { dalam } \\
\text { melaksana } \\
\text { kan } \\
\text { pembelaja } \\
\text { ran } \\
\text { melalui } \\
\text { Model } \\
\text { pembelaja } \\
\text { ran M2E }\end{array}$ & $\begin{array}{l}\text { mengetah } \\
\text { ui konsep } \\
\text { dari buku } \\
\text { teks yang } \\
\text { mereka } \\
\text { pegang, } \\
\text { tetapi dari } \\
\text { strategi } \\
\text { pembelaja } \\
\text { ranyang } \\
\text { digunakan }\end{array}$ & $\begin{array}{l}\text { kan tanya } \\
\text { jawab tentang } \\
\text { isi materi } \\
\text { dengan } \\
\text { menggunakan } \\
\text { model picture } \\
\text { and picture }\end{array}$ \\
\hline 5. & $\begin{array}{l}\text { Waktu } \\
\text { Pembelaja } \\
\text { ran sudah } \\
\text { sesuai } \\
\text { dengan } \\
\text { waktu } \\
\text { yang telah } \\
\text { direncana } \\
\text { kan. }\end{array}$ & $\begin{array}{l}\text { Sebagian } \\
\text { kecil siswa } \\
\text { masih ada } \\
\text { kecenderu } \\
\text { ngan } \\
\text { bersikap } \\
\text { acuh, dan } \\
\text { tidak } \\
\text { membantu } \\
\text { temannva. }\end{array}$ & $\begin{array}{l}\text { Guru lebih } \\
\text { memotivasi } \\
\text { siswa akan } \\
\text { pentingnya } \\
\text { bekerja sama } \\
\text { dalam } \\
\text { kelompok }\end{array}$ \\
\hline
\end{tabular}

Tabel 5: Hasil Refleksi Siklus II

Berdasarkan hasil belajar siswa, serta hasil observasi terhadap kemampuan guru merancang RPP, aktivitas guru dalam proses pembelajaran dan aktivitas belajar siswa pada pembelajaran Alquran-Hadits di Kelas X IPA MAS Argayasa Kabupaten Ciamis pada pelajaran Alquran-Hadits pada "pengertian hadits, sunah, khobar dan atsar" dengan menggunakan Model pembelajaran M2E pada siklus II sudah dilakukan dengan sangat baik dan mengalami peningkatan, serta berdasarkan data hasil rata-rata post test menunjukan peningkatan dari siklus I dan telah melampaui target $79 \%$ yakni mencapai 80,53. Dengan demikian tim peneliti sepakat menghentikan penelitian sampai dengan siklus II.

Jadi, berdasarkan hasil penelitian tindakan kelas pada pembelajaran Alquran-Hadits materi "Pengertian hadits, sunah, khobar dan atsar" di Kelas X IPAMAS Argayasa Kabupaten Ciamis semester dua, melalui penerapan Model pembelajaran M2E (Mapping, Matrix and Elaboration). Penelitian ini dilakukan oleh peneliti sebagai guru mata pelajaran AlquranHadits kelas IX, dan berkolaborasi dengan guru mata pelajaran Alquran-Hadits kelas VII sebagai observer. Hasil penelitian yang dilaksanakan sebanyak 2 siklus, untuk lebih jelasnya dapat dilihat rekapitulasi hasil tindakan siklus I dan II pada tabel berikut ini : 


\begin{tabular}{|l|l|c|c|}
\multirow{2}{*}{$\begin{array}{l}\text { No } \\
\cdot\end{array}$} & Jenis & \multicolumn{2}{|c|}{ Kegiatan } \\
\cline { 3 - 4 } & $\begin{array}{l}\text { Perencana } \\
\text { an } \\
\text { Pembelajar } \\
\text { an }\end{array}$ & $62,14 \%$ & $80 \%$ \\
\hline 2 & $\begin{array}{l}\text { Aktivitas } \\
\text { guru dalam } \\
\text { pembelajar } \\
\text { an }\end{array}$ & $61,5 \%$ & $78 \%$ \\
\hline 3 & $\begin{array}{l}\text { Akltivitas } \\
\text { Siswa } \\
\text { dalam } \\
\text { pembelajar } \\
\text { an }\end{array}$ & $65 \%$ & $80 \%$ \\
\hline 4 & $\begin{array}{l}\text { Hasil } \\
\text { Belajar } \\
\text { Siswa }\end{array}$ & $70,05 \%$ & $80,53 \%$ \\
\hline \multicolumn{2}{|l|}{ Rata-rata } & $64,72 \%$ & $79,70 \%$ \\
\hline
\end{tabular}

Tabel 6: Rekapitulasi Hasil Penelitian

Dari tabel di atas dapat dibuat grafik perbandingan hasil tindakan siklus I dan siklus II sebagai berikut:

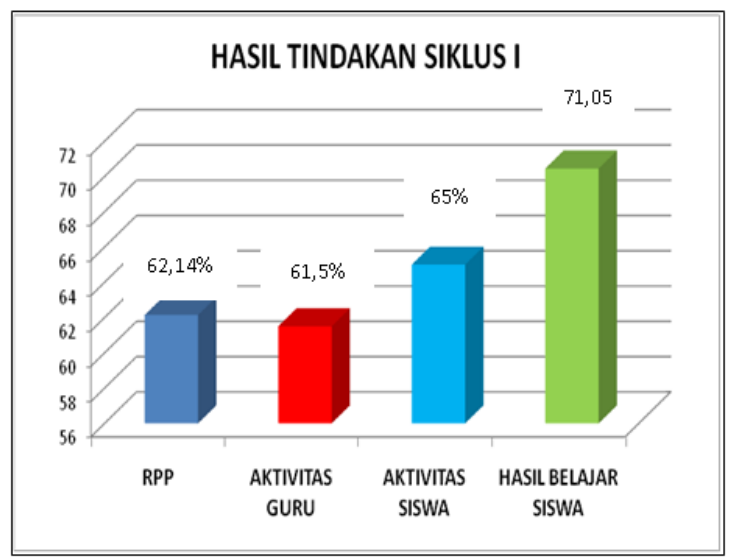

Grafik 1: Hasil Tindakan Siklus I

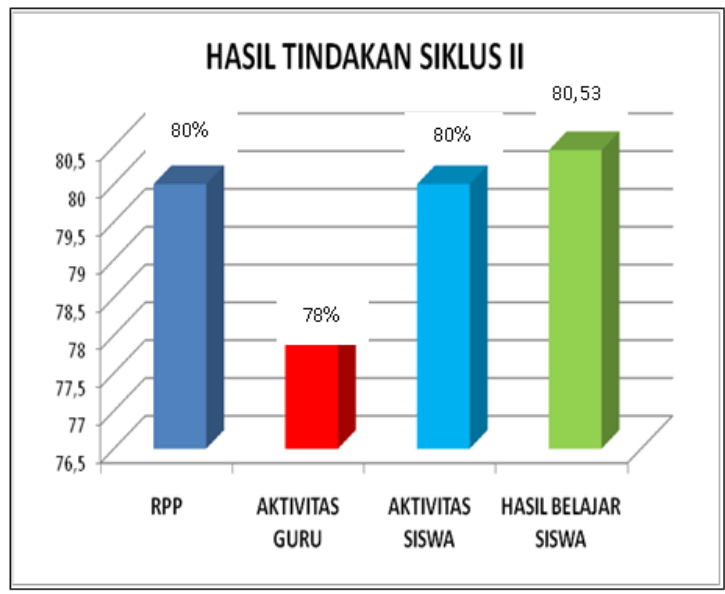

Grafik 2 Hasil Tindakan Siklus II
Dari tabel dan grafik di atas, menunjukan bahwa hasil penelitian tindakan kelas pada pembelajaran Alquran-Hadits materi pokok "pengertian hadits, sunah, khobar dan atsar" di Kelas X IPA MAS Argayasa Kabupaten Ciamis semester dua melalui penerapan model pembelajaran M2E (Mapping, Matrix and Elaboration), dari siklus ke siklus terjadi peningkatan, baik kemampuan guru membuat perencanaan, melaksanakan pembelajaran, dan aktivitas siswa dalam mengikuti pembelajaran, serta hasil belajar siswa.

\section{SIMPULAN}

Berdasarkan hasil penelitian tindakan kelas yang dilaksanakan pada pembelajaran AlquranHadits materi pokok "pengertian hadits, sunah, khobar dan atsar" melalui penerapan Model pembelajaran M2E di Kelas X IPA MAS Argayasa Kabupaten Ciamis semester dua, dapat disimpulkan sebagai berikut :

1. Kemampuan guru dalam membuat perencanaan pembelajaran Alquran-Hadits materi pokok "Pengertian hadits, sunah, khobar dan atsar" di Kelas X IPA MAS Argayasa Kabupaten Ciamis semester dua, melalui Model pembelajaran M2E (Mapping, Matrix and Elaboration), dari siklus ke siklus menunjukan adanya peningkatan yang baik yaitu dengan hasil sebagai berikut siklus I $62,14 \%$ dan siklus II $80 \%$.

2. Kemampuan guru dalam melaksanakan proses pembelajaran Alquran-Hadits materi pokok "pengertian hadits, sunah, khobar dan atsar" di Kelas X IPA MAS Argayasa Kabupaten Ciamis semester dua, melalui Model pembelajaran M2E (Mapping, Matrix and Elaboration) dari siklus ke siklus menunjukan adanya peningkatan yang baik dengan hasil siklus I 61,5\% dan siklus II 78\%. Demikian juga aktivitas siswa dalam mengikuti pembelajaran dari siklus ke siklus menunjukan peningkatan yang baik yaitu siklus I $65 \%$ dan siklus II $80 \%$.

3. Hasil belajar siswa pada pembelajaran Alquran-Hadits materi pokok "pengertian hadits, sunah, khobar dan atsar" di Kelas X IPA MAS Argayasa Kabupaten Ciamis semester dua, melalui Model pembelajaran M2E (Mapping, Matrix and Elaboration), dari siklus ke siklus menunjukan adanya peningkatan yang cukup baik sesuai yang diharapkan, yaitu siklus I 71,05; dan siklus II 80,53. Hasil pada siklus II ini sudah 
melampaui KKM pelajaran Alquran-Hadits sebesar 75 .

\section{DAFTAR RUJUKAN}

Agusta, Aisha, M Priyatna, and Agus Saripudin. "Pengaruh Hafalan Alquran Terhadap Prestasi Belajar Pada Mata Pelajaran Alquran Hadist Kelas XI IPA.” In Prosiding Al Hidayah Pendidikan Agama Islam, 131-37, 2018.

Anggrawan, Anthony. "Analisis Deskriptif Hasil Belajar Pembelajaran Tatap Muka Dan Pembelajaran Daring Menurut Gaya Belajar Mahasiswa." Jurnal Matrik 18, no. 2 (2019): 339-46.

Arikunto, Suharsimi. Penelitian Tindakan Kelas. Jakarta: Bumi Aksara, 2010.

Djamarah, Syaiful Bahri, and Sopian. Psikologi Belajar. Jakarta: Rineka Cipta, 2012.

Jalaluddin, and Abdullah Idi. Filsafat Pendidikan: Manusia, Filsafat Dan Pendidikan. Depok: Raja Grafindo Persada, 2016.

Mardhiyah, M. Dahlan R, and Tjetjep Suhandi. "Strategi Guru Dalam Meningkatkan Motivasi Belajar Peserta Didik Pada Mata Pelajaran Al-Qur'an Dan Hadits." Fikerah: Journal Of Islamic Education 2, no. 1 (2018): 112.

Mulyasa, E. Menjadi Guru Profesional (Menciptakan Pembelajaran Kreatif Dan Menyenangkan). Bandung: Remaja Rosdakarya, 2016.

Nana Sudjana. Dasar-Dasar Proses Belajar Mengajar. Bandung: Sinar Baru Algesindo, 2010.

Subekhan, Moch., and Dea Umyati. "Pengaruh Metode Pembelajaran Talking Stick Terhadap Keaktifan Belajar Siswa Pada Mata Pelajaran Al-Qur'an Dan Hadits." Geneologi P AI: Jurnal Pendidikan Agama Islam 6, no. 1 (2019): 51-68. doi:10.32678/geneologipai.v6i1.1943.

Sugiyono. Statistika Untuk Penelitian. Bandung: Alfabeta, 2005.

Syah, Muhibbin. Psikologi Pendidikan Dengan Suatu Pendekatan Baru. Bandung: Remaja Rosdakarya, 2010.

Trianto. Mendesain Strategi Pembelajaran Inovatif Progresif. Jakarta: Prenadamedia Group, 2007.

Winarno Surakhmad. Pengantar Dan Teknik.
Penelitian Ilmiah. Bandung: Tarsito, 2008.

Winkel, W.S. Psikologi Pendidikan. Jakarta: Rineka Cipta, 2006. 